\title{
Celeiros da pobreza urbana: suplementação de renda e isolamento social em ambientes metropolitanos nos tempos pandêmicos
}

\section{Urban poverty barns: income supplementation and social isolation in metropolitan environments in pandemic times}

\author{
Tadeu Alencar Arrais',* (iD \\ Adriano Rodrigues de Oliveiral \\ Juheina Lacerda Viana' \\ Diego Pinheiro Alencar" (D) \\ Tathiana Rodrigues Salgado"' iD \\ Jorge Pires de Morais Neto' \\ Maria Ester de Souzalv
}

\section{RESUMO}

As regiões metropolitanas registraram, em 19 de março de 2020, 85,71\% dos óbitos e 93,3\% das ocorrências da COVID-19. Esses percentuais persistiram, com poucas variações, até o dia 18 de maio de 2020. A associação entre alta densidade, carência de infraestrutura urbana e mercado de trabalho com forte dependência da informalidade demonstrou a vulnerabilidade, do ponto de vista do contágio da COVID-19, nas periferias metropolitanas. Nesse contexto, a implementação de políticas de recomposição e suplementação de renda é necessária para, ao mesmo tempo, garantir a subsistência das famílias e facilitar as políticas de isolamento social.

PALAVRAS-CHAVE: Regiões Metropolitanas; COVID-19; Políticas Públicas

\begin{abstract}
The metropolitan regions registered on March $19^{\text {th }} 2020,85.71 \%$ of deaths and $93.3 \%$ of occurrences of COVID-19, a percentage that persisted with few variations until May $18^{\text {th }}$ 2020. The combination of high density, lack of urban infrastructure and labor market with a strong dependence on the informality demonstrated vulnerability of the metropolitan peripheries, from the point of view of the contagion of COVID-19. In this context, the implementation of policies of recomposition and supplementation of income is necessary to, at the same time, ensure the subsistence of families and facilitate the policies of social isolation.
\end{abstract}

KEYWORDS: Metropolitan Regions; COVID-19; Public Policies
I Universidade Federal de Goiás, Goiânia, GO, Brasil

" Instituto Federal Goiano, Iporá, GO, Brasil

III Universidade Estadual de Goiás, Porangatu, GO, Brasil

Iv Pontifícia Universidade Católica de Goiás, Goiânia, GO, Brasil

\footnotetext{
* E-mail: tadeuarraisufg@gmail.com
} 


\section{INTRODUÇ̃̃O}

Ela não era aposentada, porque ainda não tinha tempo de contribuição para isso. Então, mesmo com obesidade, diabetes, hipertensão e infecção urinária, ela continuou trabalhando. Ela precisava do dinheiro (Depoimento do irmão da primeira vítima do Coronavírus, moradora do município de Miguel Pereira, RJ. UOL Notícias, 19/03/202011).

A evolução da pandemia, provocada pela COVID-19, e a relutância de uma parte da população em adotar o isolamento social colocaram morro abaixo a ideia de que os efeitos da crise, traduzidos no número de óbitos, no desemprego e na redução da massa de rendimento familiar, são socializados. A crise desnudou a equivalência entre a desigualdade espacial e a desigualdade social. É ingenuidade acreditar que todos os espaços serão atingidos com a mesma velocidade e intensidade, assim como imaginar que todos os grupos sociais sofreram, sofrem ou sofrerão do mesmo modo. A imagem, sensibilizadora, das covas coletivas na cidade de Manaus, não revela o conteúdo dos caixões, composto por pobres privados de sua individualidade ${ }^{2}$. Somente no final da guerra será possível contabilizar as baixas e saber o destino dos espólios. Em um planeta urbano, marcado pela desigualdade social e concentração da pobreza, os efeitos da crise podem ser apocalípticos. Em 2006, Mike Daves, autor de "O monstro bate à nossa porta: a ameça global da crise aviária”, profetizou: “[...] a globalização econômica sem o concomitante investimento em infraestrutura global de saúde pública é uma fórmula certeira da catástrofe" ${ }^{3}$.

A pandemia tem o poder de desestruturar os frágeis sistemas de saúde e o mercado de trabalho nos ambientes urbanos mais densos do planeta, exigindo, primeiramente, investimento integrado em pesquisa científica e, em segundo lugar, interferência do Estado em distintos campos da economia, decisão defendida até mesmo pelos arautos do liberalismo ${ }^{4}$. A disputa, não amanhã, mas desde ontem, opera-se nos seguintes campos:

- No financiamento da produção, por meio de instrumentos de transferência direta de recursos e desonerações fiscais para empresas e corporações;

- No financiamento e/ou renegociação da dívida pública de estados e municípios para saldarem despesas de custeio, especialmente a folha de pagamento;

- No financiamento e na ampliação das transferências de renda direta para os cidadãos, por meio de novos e/ou antigos instrumentos burocráticos.

A compreensão dessa ambiência de conflitos é fundamental para não cairmos na ingenuidade de imaginar que, em função da crise pandêmica, o Estado mudou sua natureza constitutiva. O Estado continua desempenhando as funções de acumulação e legitimação descritas por $0^{\prime}$ Connor $^{5}$. A crise cria, apenas, uma espécie de armistício, uma pausa para que os atores da arena política possam cunhar novas armas, estabelecer novas estratégias, afinal, a experiência do furacão Katrina (EUA) em 2005, na escala regional, assim como aquela da pandemia da gripe aviária, na escala global, provaram que as consequências de crises dessas proporções não são, plenamente, socializadas.

\section{DISCUSSÃO}

\section{Os limites do isolamento social na metrópole}

O debate sobre as transferências de renda, como medida mitigadora dos impactos econômicos do isolamento social, reaparece no cenário político. A popularização da ideia da Renda Básica de Cidadania, no Brasil, tem origem em proposta de projeto do Senador Eduardo Suplicy, em 2006 . Crises dessas proporções afetam, diretamente, a produção, o trabalho e a renda, demandando, por parte do Estado, programas de recomposição de renda. Em um país como o Brasil, no entanto, nada é tão simples, especialmente quando correlacionamos o perfil regional do emprego e da renda, com a presença de saneamento básico e a oferta de serviços públicos na área da saúde nas cidades brasileiras, de maneira geral, e nas regiões metropolitanas, de maneira específica.

O prenúncio do desastre metropolitano deveria ser antecedido por um diagnóstico que priorizasse respostas para perguntas simples, a começar por:

- como a crise, marcada pela desestruturação do mercado de trabalho formal e informal, afetará o fluxo de renda familiar dos pobres que residem nas regiões metropolitanas?

- como, diante do contexto federativo com atribuições distintas para União, Estados e Municípios, do ponto de vista da arrecadação e do volume de investimentos públicos, as demandas de infraestrutura de saneamento e saúde, represadas nas regiões metropolitanas, podem potencializar os efeitos da crise?

- como, diante dos diferentes níveis de custos de vida e erosão da renda, os pobres das periferias metropolitanas conseguirão sobreviver sem aportes de renda suplementar que ultrapassam o valor de $\mathrm{R} \$ 600,00$ e o período de 3 meses?

Nossa hipótese é a de que a crise pandêmica, manifestada pela perda de empregos formais e drástica redução do fluxo de renda do mercado informal, afetará, diferencialmente, o território brasileiro, agravando, sobremaneira, os problemas nas regiões metropolitanas e colocando, ao mesmo tempo, novos desafios para as políticas emergenciais nas áreas da saúde e suplementação de renda. Sendo espacialmente diferenciais, as políticas de recomposição e suplementação de renda também deveriam diferenciar-se no território, centrando energias para as regiões metropolitanas e suas respectivas periferias.

As regiões metropolitanas acumulam população, mercado de consumo e, fundamentalmente, oferta de equipamentos médicos hospitalares que atendiam, de modo ineficiente, as demandas regionais, consequentemente, acumulam os maiores números de casos da COVID-19 (Figura 1). A disposição pretérita de leitos para Unidades de Tratamento Intensivo (UTI) já estava 
centralizada nos espaços metropolitanos, fato agravado pela crise, uma vez que a demanda, agora multiplicada, continuará sendo drenada para os cores metropolitanos. 0 chamado free rider é uma realidade nos espaços metropolitanos e regionais. As capitais estaduais, em 2019, concentravam $42,89 \%$ dos leitos de UTI do Sistema Único de Saúde (SUS) e $56,16 \%$ dos leitos UTI privados, o que dá a exata noção de como as áreas metropolitanas também drenarão as demandas regionais por respiradores ${ }^{7}$.

O que salta aos olhos, considerando o território brasileiro, é a densidade demográfica das regiões metropolitanas e de suas respectivas periferias. Mas, a densidade não revela a essência do fenômeno. A densidade, como aparência, é um ponto de partida potencial para explicar os efeitos diferenciais da crise. É necessário considerar a relação entre densidade e infraestrutura de saneamento, fator que potencializa os efeitos devastadores das epidemias modernas. Da população estimada de 210.147.125 habitantes, em 2019, 121.996.741 residiam em regiões metropolitanas $^{8}$. Entretanto, as regiões metropolitanas são apenas um ponto de partida nesse jogo de consequências escalares. Tomemos como referência os "Aglomerados Subnormais", topônimo institucional que tenta traduzir a diversidade de formas de ocupação marcadas, genericamente, pela posse ilegal da terra, padrão urbanístico irregular e carência de serviços. Em cada metrópole, a depender da ecologia urbana, o conceito de "Aglomerado Subnormal" pode ser substituído por invasão, mocambo, palafita, grotão, favela, comunidade. Em 2010, havia 15.868 "Aglomerados Subnormais", totalizando 3.224.529 domicílios e 11.425 .644 habitantes, equivalente a $5,98 \%$ da população brasileira ${ }^{10}$.

O exercício estatístico demostra algo óbvio na paisagem urbana. A densidade demográfica nos "Aglomerados Subnormais" é maior do que a média dos respectivos municípios em que eles estão inseridos, conforme apresentado na Tabela. A densidade, no entanto, responde apenas por uma parte da equação. Em 2018, $15,1 \%$ da população vivia sem abastecimento de água, sendo que os brancos somavam $11,5 \%$ e os negros e pardos, $17,9 \%$. A ausência de esgotamento sanitário por rede coletora ou pluvial foi registrada em domicílios que residem $35,7 \%$ da população, sendo $23,5 \%$ para a população branca e $42,8 \%$ da população preta ou parda ${ }^{11}$. 0 problema, além da inconsistência na oferta, não registrada na estatística, está no fato de a escassez ser concentrada nas periferias metropolitanas.

A associação entre condições ecológicas dos sítios urbanos e a disposição de infraestrutura de saneamento básico e a oferta de

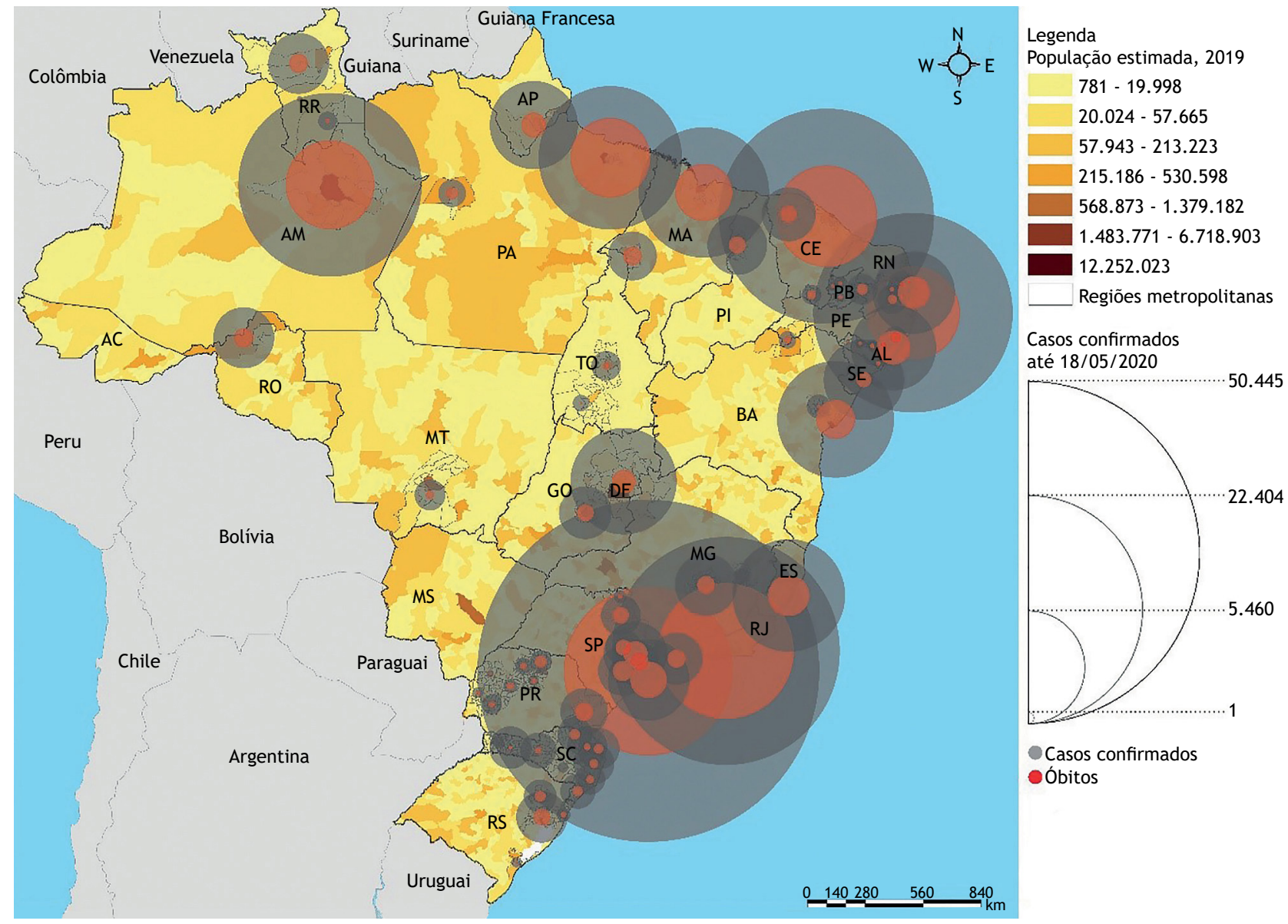

Fonte: Elaborado pelos autores com base nos dados de IBGE $^{8}$ e Secretarias Estaduais de Saúde 9

Figura 1. Brasil: População das regiões metropolitanas; ocorrência de casos de COVID-19 é número do óbitos até 18/05/20. 
Tabela. População total dos municípios, em 2019, e dados dos “Aglomerados Subnormais” de municípios selecionados, 2010.

\begin{tabular}{|c|c|c|c|c|c|}
\hline Município & $\begin{array}{l}\text { População total } \\
-2019\end{array}$ & $\begin{array}{c}\text { Densidade } \\
\text { demográfica } \\
\text { municipal }\left(\mathrm{Km}^{2}\right)\end{array}$ & $\begin{array}{l}\text { População total vivendo } \\
\text { em “Aglomerados } \\
\text { Subnormais" - } 2010\end{array}$ & $\begin{array}{l}\text { Total de "Aglomerados } \\
\text { Subnormais" - } 2010\end{array}$ & $\begin{array}{c}\text { Densidade demográfica dos } \\
\text { "Aglomerados Subnormais", } \\
\mathrm{Km}^{2}-2010\end{array}$ \\
\hline Belém & 1.492 .745 & $1.315,26$ & 758.524 & 193.557 & $9.331,82$ \\
\hline Distrito Federal & 3.015 .268 & 444,66 & 133.556 & 36.504 & $3.809,35$ \\
\hline Fortaleza & 2.669 .642 & $7.786,44$ & 396.370 & 109.122 & $12.611,39$ \\
\hline Goiânia & 1.516 .113 & $1.776,74$ & 3.495 & 1.066 & $4.267,39$ \\
\hline Porto Alegre & 1.483 .771 & $2.837,53$ & 192.842 & 56.024 & $8.287,39$ \\
\hline Recife & 1.645 .627 & $7.039,64$ & 349.420 & 102.392 & $12.321,12$ \\
\hline Rio de Janeiro & 6.718 .903 & $5.265,82$ & 1.393 .314 & 426.965 & $25.702,15$ \\
\hline Salvador & 2.872 .347 & $3.859,44$ & 882.204 & 275.593 & $14.514,70$ \\
\hline São Paulo & 12.252 .023 & $7.398,26$ & 1.280 .406 & 355.756 & $29.749,21$ \\
\hline
\end{tabular}

Fonte: IBGE 8,10 .

serviços públicos oferece uma imagem distinta do drama dos brasileiros. É diferente, pois, manter-se em isolamento social nas palafitas de Belém (PA) ou Manaus (AM), nos Morros de Salvador (BA) ou nos fundos de vale de Goiânia (GO). Conforto térmico e acústico, ventilação adequada, afastamentos e recuos frontais e laterais são conceitos desconhecidos na arquitetura de sobrevivência. A reprodução da vida, na escala domiciliar, em virtude da densidade da ocupação, transforma o isolamento social em tortura. A ausência de meios monetários para suprir as demandas básicas de alimentação e higiene pessoal também obriga parte significativa da população a acionar a escala da cidade para trabalhar, uma vez que, os meios para garantir a subsistência, via trabalho formal e informal, estão em xeque. Essa engenharia aumenta as possibilidades de contágio e consequente contaminação comunitária.

Uma parcela significativa dos pobres vive situações que podem, aos olhos do observador comum, ser entendidas como opções ou mesmo escolhas resultantes de hábitos comunitários. Lavar as mãos antes das refeições, hábito banal, pode não ser comum em ambientes sem rede de água. Nas regiões metropolitanas de Belém e Macapá, por exemplo, 35,70\% e 43,01\% dos domicílios, respectivamente, não possuíam acesso à água via rede geral em $2010^{12}$. Para um morador do Leblon, na cidade do Rio de Janeiro, ou dos Jardins, na cidade de São Paulo, sair ou não de casa, pode, sim, resultar de uma escolha individual, uma vez que os meios de subsistência, traduzidos na renda, estão garantidos. Para os pobres, essa escolha, frequentemente, transforma-se em dilema, adquirindo contornos dramáticos: perecer em casa, suportando as dificuldades impostas pela densidade e ausência dos serviços públicos, ou arriscar-se nas ruas, em busca de suplementação de renda, tal foi o exemplo da doméstica de Miguel Pereira, contagiada pela patroa, recém-chegada da Europa, residente do Leblon'1.

\section{A sobrevivência dos pobres metropolitanos}

Uma vendedora ambulante de Pirambu (Fortaleza - CE) pode orgulhar-se de ver o sol nascer primeiro que um servente de pedreiro que reside em Paraisópolis (São Paulo - SP). A distância de 3.098 $\mathrm{Km}$ camufla a proximidade das realidades sociais, do mesmo modo que o sol anuncia destinos diferentes para turistas e uma miríade de trabalhadores que residem nas periferias litorâneas. A ambulante de Pirambu e o servente de pedreiro de Paraisópolis estão inseridos em diferentes redes de renda monetária. A renda do trabalho informal da ambulante e a do trabalho formal do pedreiro são, no núcleo familiar, complementados por rendas resultantes de programas de transferências de renda, auxílios previdenciários pecuniários temporários e/ou permanentes e também pelas transferências de renda indiretas, como subsídios para consumo de serviços, a exemplo das tarifas sociais de energia. O Quadro oferece um demonstrativo do volume dos principais benefícios de transferência de renda do Brasil no ano de 2019.

A tarefa de caracterizar, do ponto de vista da renda, as regiões metropolitanas, será, sempre, incompleta. A aproximação, no entanto, é necessária, uma vez que, conforme anunciada em nossa hipótese, a crise afetará e continuará afetando, de forma diferente, a população mais vulnerável das regiões metropolitanas. É importante não perder de vista as mutações no universo do trabalho, assim como a emergência daquilo que Ricardo Antunes chamou de novo proletariado dos serviços ${ }^{15}$. Essas mudanças, mesmo considerando o peso do setor de comércio e serviços nas áreas metropolitanas, atinge a globalidade do mercado de trabalho. A vulnerabilidade, portanto, encontra-se tanto no espaço do intramercado formal (indústria, construção civil, administração pública, comércio, serviços etc.) quanto no espaço global da informalidade, algo que pode ser demonstrado pela agenda de reformas estruturais, a exemplo da Reforma Trabalhista e da Reforma da Previdência que têm, em comum, a eliminação da esperança da mobilidade social vertical a partir do trabalho, algo comum, como no regime de acumulação fordista.

A Figura 2 informa o total de trabalhos formais, em 31 de dezembro de 2018. 0 importante é compreender quais são os setores mais vulneráveis à crise. A vulnerabilidade tem estreita relação com a dispersão geográfica dos setores. Dos 46.631 .115 empregos formais, 26.448.347 concentravam-se nos setores de comércio e serviços que, por sua vez, são, do ponto de vista relativo e do ponto de vista do volume geral, mais relevantes nas regiões metropolitanas ${ }^{16}$. É possível, de modo geral, arriscar-se a dizer que, quanto mais populoso o município, mais relevantes serão, proporcionalmente, o peso do setor de serviços e o comércio na geração de empregos formais. A espacialização desse setor pode ser observada na Figura 3. 0 oposto ocorre quando consideramos a participação, no total de empregos formais, do segmento da 
Quadro. Total de benefícios, valor e percentual dos benefícios e transferências de renda selecionados.

\begin{tabular}{|c|c|c|c|c|c|c|c|}
\hline \multirow{2}{*}{$\begin{array}{l}\text { Tipo do } \\
\text { benefício }\end{array}$} & \multirow[b]{2}{*}{ Público-alvo } & \multicolumn{2}{|c|}{ Brasil } & \multicolumn{2}{|c|}{ Regiões Metropolitanas } & \multicolumn{2}{|c|}{ Percentual } \\
\hline & & $\begin{array}{l}\text { Benefícios } \\
\text { Concedidos }\end{array}$ & Valor (R\$) & $\begin{array}{l}\text { Benefícios } \\
\text { Concedidos }\end{array}$ & Valor (R\$) & $\begin{array}{l}\text { Benefícios } \\
\text { Concedidos }\end{array}$ & Valor (R\$) \\
\hline Cadastro Único & $\begin{array}{c}\text { Família com rendimento de até } \\
\text { meio salário mínimo per capita, } \\
\text { ou renda mensal total de até } 3 \\
\text { salários mínimos }\end{array}$ & 28.884 .000 & Não se aplica & 12.778 .945 & Não se aplica & 44,24 & Não se aplica \\
\hline Bolsa Família & $\begin{array}{c}\text { Famílias em situação de pobreza } \\
\text { (renda mensal } R \$ 89,01 \text { a } R \$ \\
170,00 \text { ) e extrema pobreza (renda } \\
\text { mensal de até } R \$ 89,00 \text { ) }\end{array}$ & 13.170 .607 & 31.159 .235 .696 & 5.245 .737 & 11.760 .104 .804 & 39,83 & 37,74 \\
\hline $\begin{array}{l}\text { Aposentadoria } \\
\text { Rural }\end{array}$ & $\begin{array}{c}60 \text { anos para homens e } 55 \text { anos } \\
\text { para mulheres, com } 1 \text { salário } \\
\text { mínimo }\end{array}$ & 9.605 .988 & 112.587 .210 .484 & 2.067 .645 & 24.395 .484 .773 & 21,52 & 21,67 \\
\hline $\begin{array}{l}\text { Benefício de } \\
\text { Prestação } \\
\text { Continuada * }\end{array}$ & $\begin{array}{c}1 \text { salário mínimo para pessoas } \\
\text { com deficiência e idosos pobres, } \\
\text { com renda per capita de meio } \\
\text { salário mínimo }\end{array}$ & 4.627 .589 & 50.887 .635 .753 & 884.775 & 9.711 .350 .330 & 19,12 & 19,08 \\
\hline $\begin{array}{l}\text { Aposentadoria } \\
\text { (INSS) }^{* *}\end{array}$ & $\begin{array}{l}\text { Idade, tempo de serviço ou } \\
\text { invalidez }\end{array}$ & 21.265 .516 & 377.005 .815 .638 & 10.574 .049 & 216.65 .404 .976 & 49,72 & 57,39 \\
\hline $\begin{array}{l}\text { Pensão por } \\
\text { morte }\end{array}$ & $\begin{array}{l}\text { Dependentes de trabalhadores } \\
\text { vinculados ao INSS }\end{array}$ & 6.756 .455 & 126.757 .465 .976 & 4.0036 .080 & 71.362 .179 .097 & 59,025 & 26,30 \\
\hline
\end{tabular}

Fonte: $\mathrm{MDS}^{13}$, INSS ${ }^{14}$.

INSS: Instituto Nacional do Seguro Social.

* Valores repassados entre os meses de janeiro e novembro.

** Soma global, incluído os benefícios rurais.

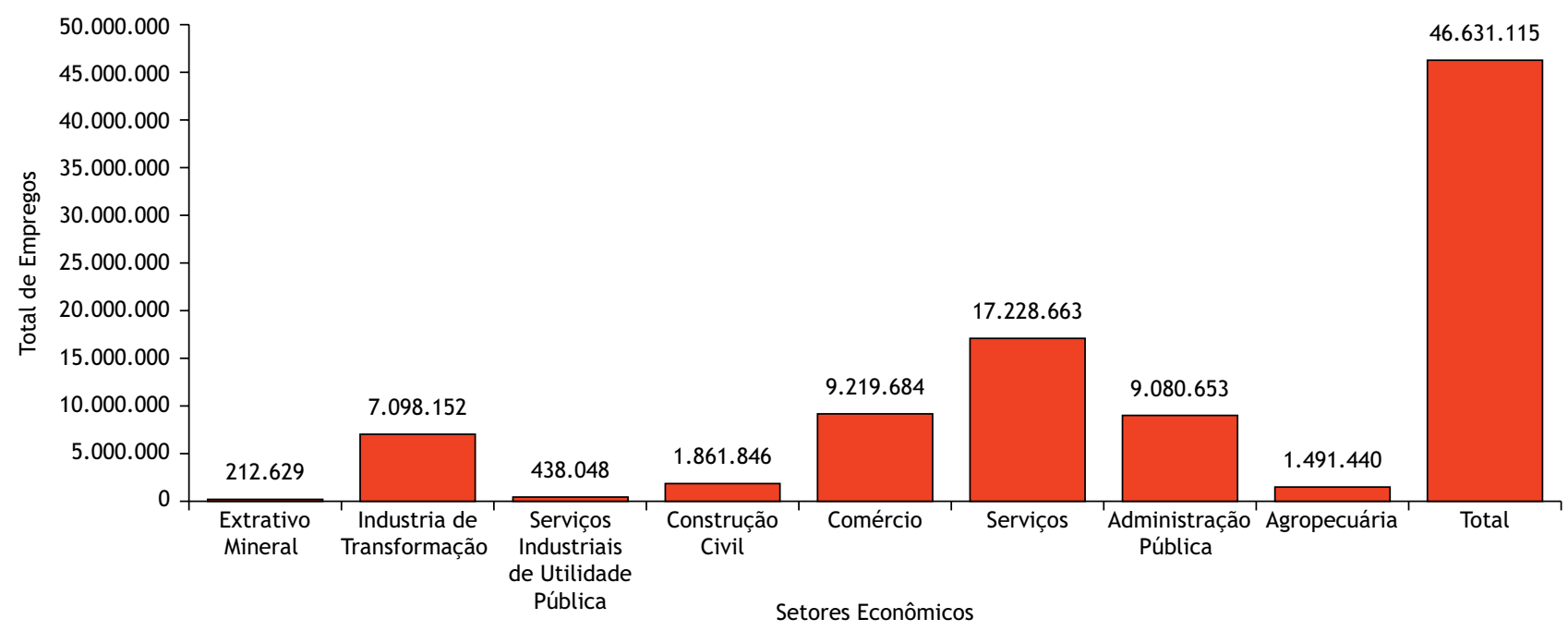

Fonte: Elaborado pelos autores com base nos dados de $\mathrm{MTE}^{16}$.

Figura 2. Brasil, total de empregos formais, por setor, em 31 de dezembro de 2018.

administração pública, mais importante, do ponto de vista relativo, nos municípios menos populosos. Não é por acaso que, no município de São Paulo, os dois setores tenham representado, em $2018,71,62 \%$ do total de empregos formais, maior que os $56,71 \%$ registrados no Brasil ${ }^{16}$. Nos dois setores, a remuneração média só não é menor do que a aquela registrada no setor agropecuário e, exceção feita para a administração pública, as mulheres têm menor remuneração que os homens nos demais setores ${ }^{16}$.

Mas, os baixos níveis de remuneração dos setores formais que mais empregam nas regiões metropolitanas estão longe de traduzir, ainda, os níveis de precarização do trabalho. 0 processo de precarização é como uma pirâmide de base não determinada, motivo pelo qual sempre será possível pensar em novos graus de precarização. A espacialização dos totais de microempreendedor individual (MEI), apresentada na Figura 4, revela outro retrato dessa precarização. No intervalo de 10 anos, o total de MEI passou de 116.102 (ano de 2010) para 9.749.416 (ano de 2020) ${ }^{17}$.

Apenas no município de São Paulo, em 2020, foram registrados 795.435 trabalhadores nessa modalidade ${ }^{17}$. Em termos comparativos, mesmo com defasagem de pouco menos de dois anos na escala temporal, o setor da construção civil empregou, em São Paulo, 515.190 trabalhadores $^{16}$. A precarização do trabalho é um fenômeno com forte incidência nas regiões metropolitanas. Nacionalmente, o maior estoque de cadastro no MEl em março 


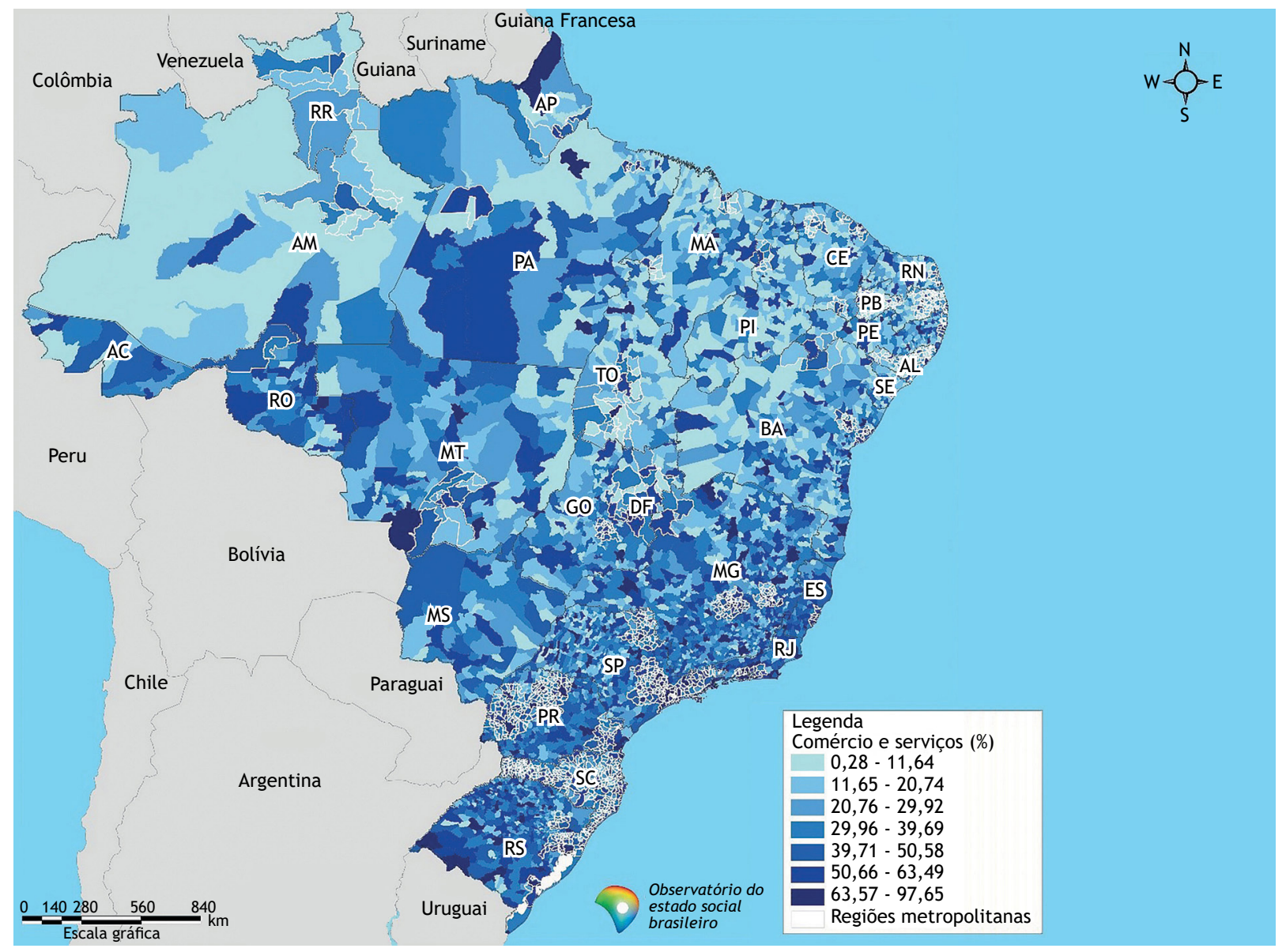

Fonte: Elaborado pelos autores com base nos dados de MTE ${ }^{16}$.

Figura 3. Percentual de empregos do comércio e serviços em relação ao total de empregos formais, dezembro de 2018.

de 2020 foi de cabeleireiro, manicure e pedicure, com 774.256 vínculos, seguido de comércio varejista de artigos do vestuário e acessórios, com 733.130 vínculos e promoção de vendas, com 323.148 vínculos $^{17}$. Os dados revelam, além do intenso processo de terceirização do trabalho, uma erosão estrutural do Regime Geral de Previdência (INSS), uma vez que a contribuição patronal é dispensada. Essa montanha de gente, hoje microempreendedores, amanhã pobres sem previdência, sobreviverá, caso tenham sorte, dos benefícios assistências da Seguridade Social.

É compreensível, estando o emprego formal concentrado nas regiões metropolitanas, que o mesmo ocorra com o desemprego (Figura 5). A vulnerabilidade nos ambientes metropolitanos, nesse sentido, toma tons mais cinzas. Comparando com as médias estaduais, a taxa de desocupação é maior em todas as capitais. A diferença entre os estados e as capitais, no entanto, ainda não revela a complexidade do desemprego que refletiu, em 11,6 milhões de pessoas ${ }^{11}$. Enquanto, no Brasil, a taxa de desocupação para homens foi 10,6, a das mulheres foi 13,8 e dos negros e pardos 14,1. Em resumo, além de localização, o desemprego tem um corte de gênero e um corte de cor, o que atinge, de modo mais perverso, os grupos mais vulneráveis do conjunto da população. Existem capitais como Belém e Macapá em que o percentual de empregos informais, no total do emprego, superou os empregos formais. Em outras oito capitais, todas do Nordeste brasileiro, o percentual de empregos informais ultrapassou os $40 \%{ }^{11}$.

Outro componente, associado ao desemprego, refere-se à variação do custo de vida. As situações de desemprego, como a registrada nos últimos anos, não reduzem as necessidades de gastos com alimentação, produtos de higiene e serviços (água, energia, gás e telefone, internet etc. ). A variação do custo de vida, demonstrada pelas séries históricas do Índice Nacional de Preços ao Consumidor (INPC), cujo foco são as famílias com renda mensal entre um e cinco salários mínimos, indica assimetrias significativas entre as metrópoles ${ }^{18}$. Em março de 2020, o Departamento Intersindical de Estatística e Estudos Socioeconômicos (DIEESE) registrou que a cesta básica mais cara, entre as capitais, foi a da cidade do Rio de Janeiro ( $R \$ 533,65)$, seguida de São Paulo ( $R \$ 518,50$ ) e Florianópolis ( $\mathrm{R} \$ 517,13)^{19}$. Os menores valores médios foram aferidos em Aracaju (R\$ 390,20) e Salvador ( $R \$ 408,06)^{18}$. No Rio de Janeiro e em São Paulo, com a cesta básica, são comprometidos 51,36\% e $49,90 \%$ do salário mínimo e em Aracaju e Salvador, 37,56\% e $39,27 \%{ }^{19}$. Os gastos com alimentação, medicamentos e serviços reforçam a necessidade de se pensar políticas de incremento de renda diferentes para esses espaços, bastando, para tanto, 


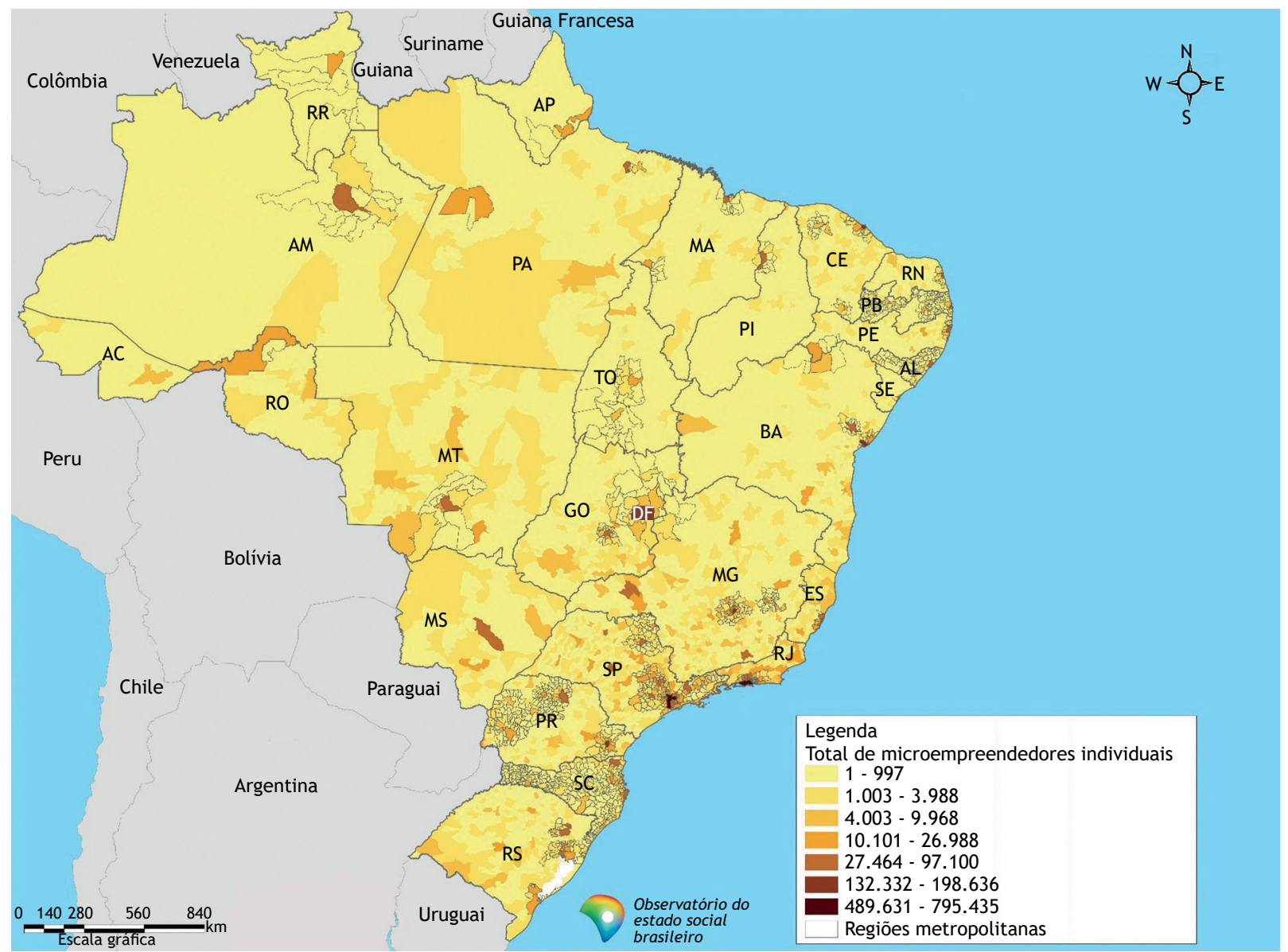

Fonte: Elaborado pelos autores com base nos dados do Portal do Empreendedor ${ }^{17}$.

Figura 4. Total de microempreendedores individuais (MEI), em janeiro de 2020.

comparar os custos do transporte coletivo que não são comuns, por exemplo, em cidades abaixo de 50 mil habitantes. A tarifa média cobrada pelo acesso a ônibus convencionais nas capitais estaduais brasileiras alcança o valor médio $\mathrm{R} \$ 4,10$. 0 maior valor, em 2020, foi registrado em Belo Horizonte, com $R \$ 5,60^{20}$ e o menor, em Recife, com $R \$ 3,45^{21}$. Essa diferença, no entanto, deve ser considerada a partir dos distintos sistemas de integração. 0 fato é que, em Recife, estimando o deslocamento casa-trabalho-casa, cinco vezes por semana, o gasto atinge $R \$ 138,00$ mensais e em Belo Horizonte R\$224,00 mensais. Procurar emprego para parcela da população pobre, portanto, tem um custo.

Sem renda do trabalho formal ou sobrevivendo de rendas esporádicas do trabalho informal precário, parte da população complementa sua renda com transferências de renda monetária diretas e com os benefícios previdenciários permanentes ou temporários. A massa da renda familiar, portanto, guarda, na sua composição, uma forte presença das transferências públicas, isso sem contar as transferências de renda indiretas, caracterizadas, em resumo, pelo acesso aos serviços de saúde e educação, além dos subsídios. No Cadastro Único para Programa Sociais, em março de 2020, havia 28,48 milhões de famílias, com abrangência maior que 60 milhões de pessoas ${ }^{23}$. Desse total de famílias com rendimento de até meio salário mínimo per capita, ou renda mensal total de até três salários mínimos, $42 \%$ concentrava-se, em 2020, nas regiões metropolitanas. Os municípios de maior concentração absoluta de inscritos são, por outro lado, aqueles de menor peso relativo, seja quando consideramos a população total municipal ou mesmo o número de famílias contempladas com benefícios do Bolsa Família ${ }^{23}$ (Figura 6).

As regiões metropolitanas concentraram $39,83 \%$ do total de benefícios do Bolsa Família. A comparação regional da cobertura, ou seja, o percentual de pessoas de baixa renda, no Cadastro Único, que recebem Bolsa Família revela distintas demandas regionais. São Paulo, Rio de Janeiro, Recife e Belém tinham, em 2020, 1.344.588, 553.651, 208.788 e 248.595 famílias inscritas no Cadastro Único e, respectivamente, 376.460, 221.858, 84.813 e 112.125 famílias que recebiam benefícios do Bolsa Família ${ }^{23}$. 0 que se nota é que os municípios das Regiões Norte e Nordeste, além do Norte de Minas Gerais e Oeste do Rio Grande do Sul, apresentam maior percentual de cobertura do Bolsa Família. É importante destacar que o valor médio do benefício por família, em 2020, foi de R\$191,86 ${ }^{23}$. Mesmo concentrando maiores demandas, do ponto de vista absoluta, as regiões metropolitanas apresentaram menor cobertura relativa. 


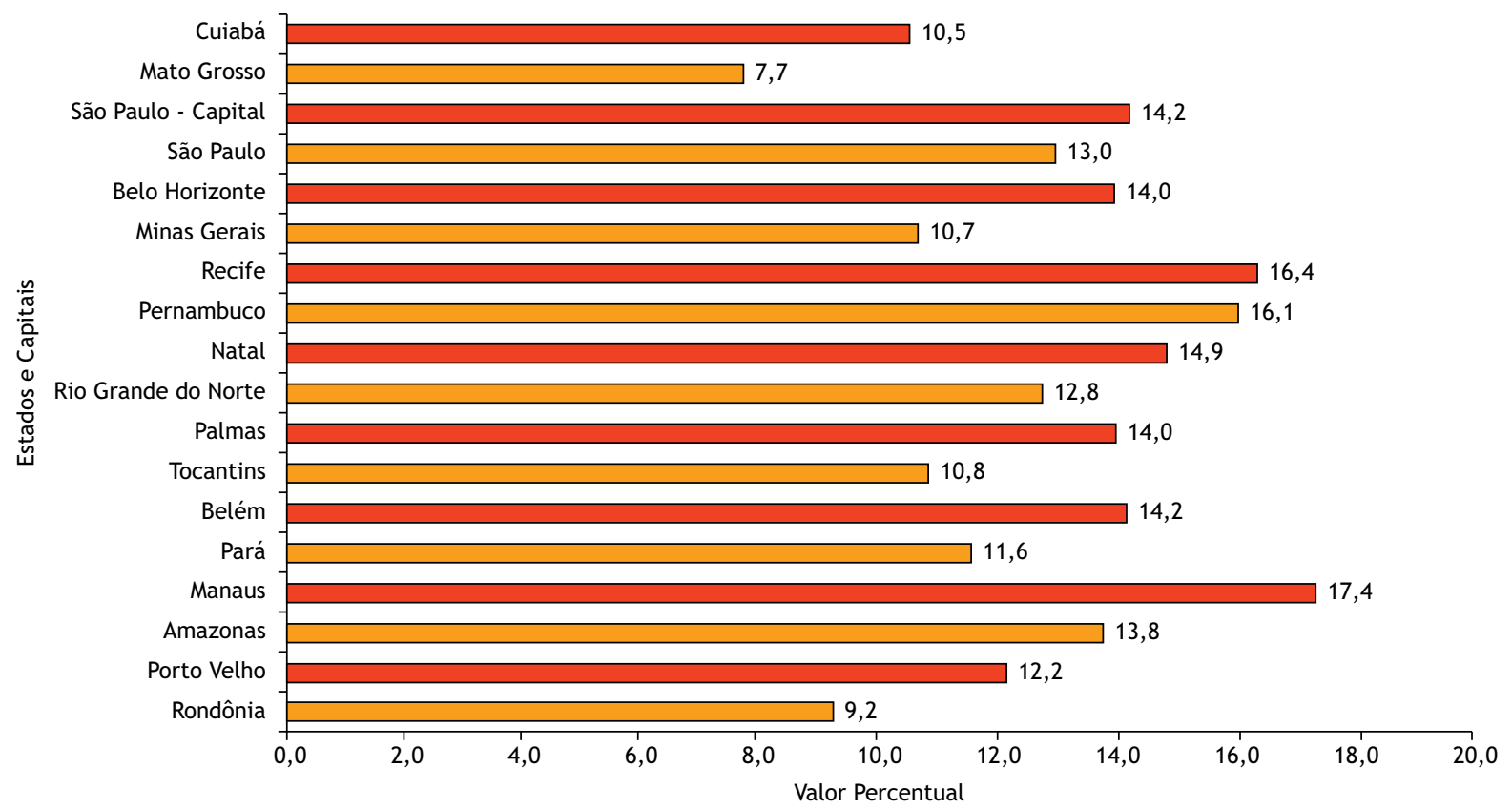

Fonte: Elaborado pelos autores com base nos dados de IBGE ${ }^{11}$.

Figura 5. Taxa de desocupação das pessoas de 14 anos ou mais de idade, por estados e capitais selecionadas, 2018.

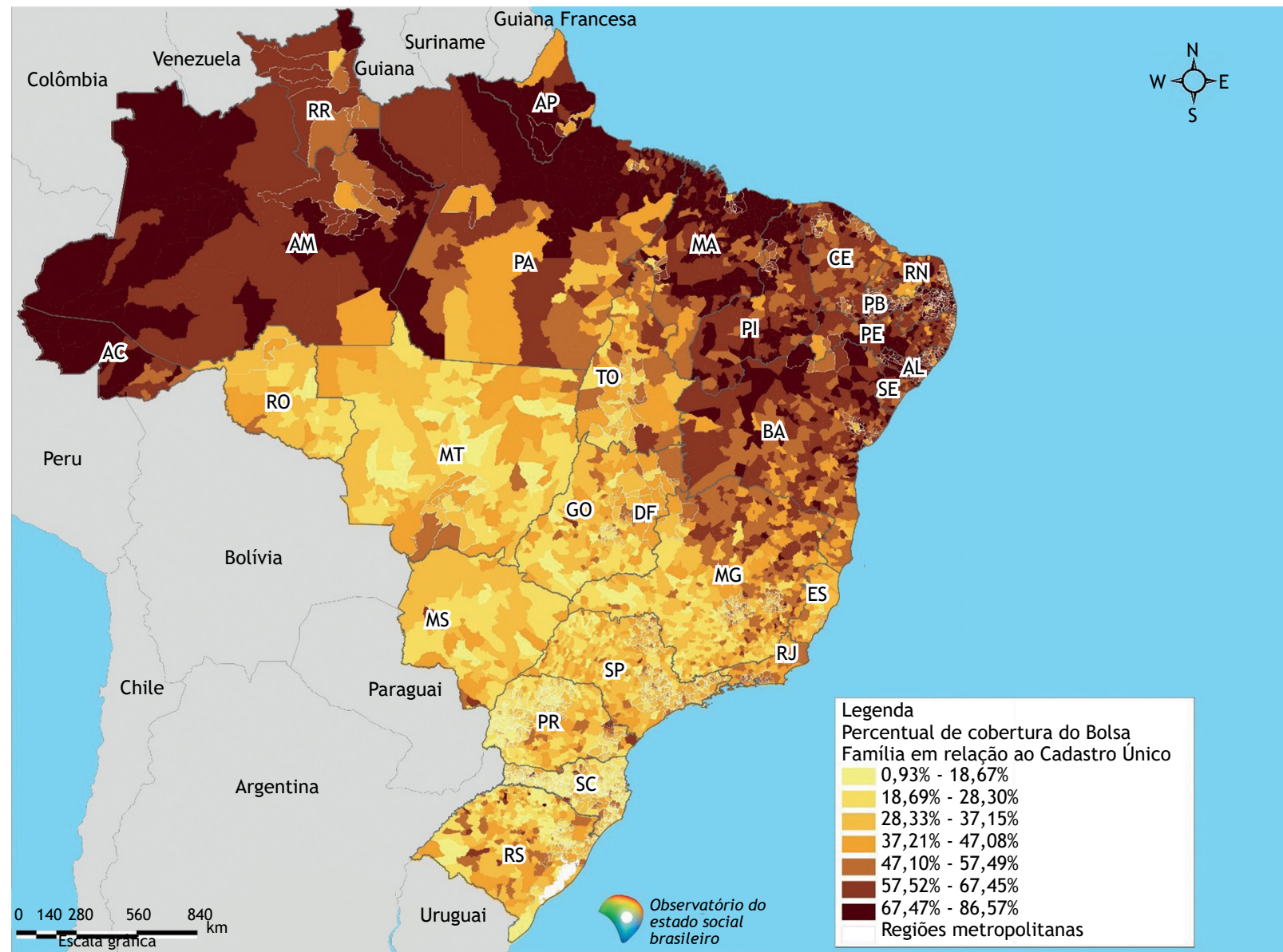

Fonte: Elaborado pelos autores com base nos dados de IBGE ${ }^{22}$ e MDS $^{13}$.

Figura 6. Percentual de cobertura do Bolsa Família em relação ao Cadastro Único, 2019. 


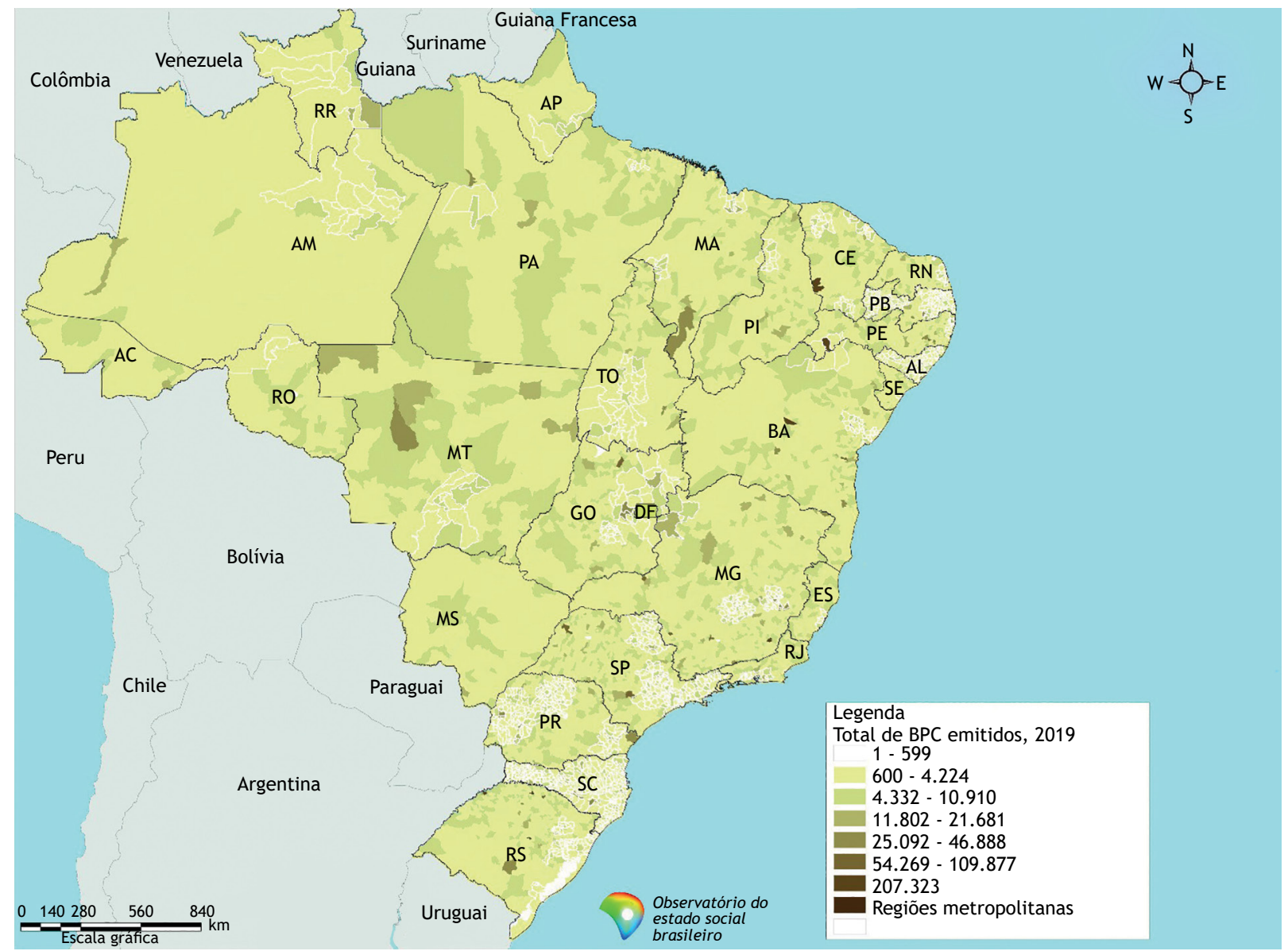

Fonte: Elaborado pelos autores com base nos dados de MDS ${ }^{13}$.

Figura 7. Brasil, total de Benefícios de Prestação Continuada, por município, em 2019.

Outros dois programas, que podem ser caracterizados como transferência de renda direta, são, em termos do total de beneficiados, menos significativos nas regiões metropolitanas. Em termos de valor, no entanto, superam, em função do valor nominal dos benefícios, os recursos do Bolsa Família. São mais de R\$ 24,39 bilhões dos benefícios da Aposentadoria Rural e de R\$ 9,5 bilhões dos Benefícios de Prestação Continuada transferidos para beneficiários que residem nas regiões metropolitanas (Figura 7). Foram emitidos, por mês, no ano de 2019, para residentes em regiões metropolitanas, 2.067 .645 benefícios da Aposentadoria Rural, 1.156.294 Benefício de Prestação Continuada para Idosos pobres e 1.151.715 Benefícios de Prestação Continuada para portadores de deficiência, totalizando $4.375 .651^{13,14}$. Os dois benefícios têm como teto o salário mínimo. É interessante notar que $56,49 \%$ dos Benefícios de Prestação Continuada para idosos e 44,64\% daqueles destinados a portadores de deficiência, em 2019, concentraram-se nas regiões metropolitanas ${ }^{13}$. Trata-se da população mais vulnerável, dispersa nas periferias das grandes cidades. Já a Aposentadoria Rural é central para a reprodução da vida diária de idosos nos municípios com características rurais e pouco populosos, como pode ser observado no Norte, no Nordeste e no Norte de Minas Gerais, entre outras áreas ${ }^{24}$. As regiões metropolitanas nordestinas têm maior peso desses benefícios que as regiões metropolitanas do Sul e Sudeste ${ }^{14}$.

As fontes de renda de maior capilaridade nas regiões metropolitanas, do ponto de vista do volume e do valor, são as aposentadorias (idade, invalidez e tempo de contribuição) e as pensões do INSS. As aposentadorias, em 2019, somaram 21.265 .616 benefícios mensais e as pensões 7.918 .484 benefícios mensais. Foram emitidos, em cada mês de 2019, aproximadamente, 26 milhões de benefícios urbanos. Do total dos benefícios do INSS, 49,9\% das aposentadorias e $50,54 \%$ das pensões concentraram-se nas regiões metropolitanas. Dos 35,6 milhões de benefícios emitidos, $59,3 \%$ são aposentadorias, $21,9 \%$ pensões e $13,3 \%$ Benefícios de Prestação Continuada. Considerando o piso previdenciário (um salário mínimo), 67,09\% dos beneficiários receberam até um salário mínimo, 16,31\% receberam acima de um até dois salários mínimos e 8,36\% receberam acima de dois até três salários mínimos. Em síntese, mais de $91 \%$ dos beneficiários recebem pouco ${ }^{14}$.

\section{O mapa metropolitano como obituário}

Um mapa crítico é, quase sempre, uma denúncia prescrita. Isso vale tanto para mapas sobre cobertura vegetal quanto, e especialmente, para os mapas temáticos sobre notificações de casos 
e óbitos resultantes da COVID-19. Nosso mapa é, nesse sentido, uma lápide coletiva, anônima, dinâmica, em contínua expansão, cuja legenda encerra um conjunto de denúncias prescritas sobre o desenvolvimento desses celeiros de gente, assim resumidas:

- São celeiros que acumulam, em função do padrão histórico de urbanização, como demostra a Figura 8, demandas por serviços públicos de saneamento básico, fundamentalmente rede de água tratada e sistemas de coleta e tratamento de esgoto.

- São celeiros que concentram, na estrutura intraurbana, espaços com padrões urbanísticos de construção domiciliar precários, altamente densos e carentes de regularização fundiária.

- São celeiros que concentram, do ponto de vista do emprego formal, expressivos vínculos com os setores de comércio e de serviços e, do ponto de vista do emprego informal, uma miríade de trabalhos precários (ambulantes, vendedores em semáforos, trabalhadoras domésticas, entregadores de fast food, motoristas de aplicativos, catadores de recicláveis etc.) que permitem a suplementação da renda familiar.

- São celeiros de intensa mobilidade intrametropolitana para trabalho cujo impacto no custo de vida, em função do preço do transporte coletivo, só não é maior que os desgastes que consomem o tempo cotidiano de trabalhadores e trabalhadoras.

- São celeiros cuja massa de rendimento familiar guarda expressiva dependência da renda de transferências monetárias públicas, a exemplo do Bolsa Família e do Benefício de Prestação Continuada.

A par desse breve obituário é possível elencar fatores que, sob a conjuntura da epidemia do coronavírus, potencializam os riscos de incêndio nesses celeiros de gente:

- As características domiciliares e do entorno tornam o isolamento social, principal estratégia de contenção da pandemia, um projeto irrealizável. Isolar-se em condomínios luxuosos ou apartamento com média de $40 \mathrm{~m}^{2}$ por pessoa não é o mesmo que isolar-se em áreas, do ponto de vista da ocupação domiciliar, superpovoadas. Segundo a Pesquisa Nacional por Amostra de Domicílios (PNAD), em 2018, dos 71 milhões de domicílios brasileiros, 22 milhões eram ocupados por quatro ou mais moradores ${ }^{25}$. Em 546 dos 6.329 "Aglomerados Subnormais”, em 2010, havia, em média, mais de 4 moradores por domicílio ${ }^{12}$. Mas o teto subnormal perde, em distância social, para o crescente número de pessoas que, sem teto, ocupam as ruas das cidades. Só na cidade de São Paulo, entre 2015 e 2019, a população que vive nas ruas aumentou mais de 50\%, atingindo um total de 24 mil almas, segundo o Censo da População em Situação de Rua $2019^{26}$. A tragédia, com a proximidade do inverno, será inevitável, cenário que será repetido em outras cidades do planeta.

- As características da massa de rendimento não permitiram, ao longo dos tempos, a formação de poupança para tempos extraordinários. Não há excedentes e nem médio prazo na gramática dos pobres descapitalizados. Mais de $46 \%$ dos inscritos no Cadastro Único, totalizando mais de 34 milhões de pessoas, são caracterizados de baixa renda. A baixa renda está relacionada à precarização e ao desemprego que atinge, majoritariamente, as regiões metropolitanas. A situação demanda, desse modo, um programa amplo de suplementação de renda que permita, ao mesmo tempo, estimular o consumo local e garantir a subsistência, algo difícil de se imaginar quando consideramos a suplementação de renda de $R \$ 600,00$, inicialmente, por três meses.

- As características funcionais e espaciais do trabalho, traduzidas nos vínculos empregatícios e nos locais de trabalho, colocaram uma parte significativa dos residentes das periferias metropolitanas em contato, por assim dizer, com a elite desterritorializada, acostumada a viajar para o exterior e consumir em espaços marcados pela aglomeração de pessoas, como os shoppings centers. É assim que a periferia absorveu, absorve e absorverá, pelo suor do trabalho e, por intermédio do contato serviçal, o vírus, tornando contaminação comunitária incontrolável.

Nada disso, no entanto, é novo. Esse modelo de urbanização, potencializador de doenças, foi inaugurado no século XIX. Nossa urbanização semeou desigualdade e colheu chagas. Engels desenvolveu uma rara análise da organização espacial das grandes cidades a partir da relação entre moradia e trabalho. Em seu texto, Engels recorda do medo generalizado dos proprietários quando, nos bairros pobres de Manchester, a cólera começou a ceifar vidas $^{27}$. Geddes, por sua vez, também denunciando as condições de desenvolvimento urbano, adjetivou as metrópoles de "pólipo", em gramática comum que acompanhou, pelo menos até o segundo quartel do século $X X$, os estudos urbanos ${ }^{28}$. As condições sanitárias urbanas, tanto na ocorrência da cólera, nas cidades inglesas, quanto na ocorrência da peste negra, na Idade Média, demonstraram que as condições ecológicas criaram o clímax para disseminação dessas doenças. John Kelly, em A grande mortandade, lembra que a peste negra consumiu 200 milhões de almas ${ }^{29}$. No século XIV as cidades medievais eram marcadas, mais até do que as cidades contemporâneas, pelas altas densidades. As cidades europeias concentravam-se, em espaços urbanos cujo raio, no interior das muralhas, dificilmente ultrapassava $2 \mathrm{Km}$. Ambientes densos, insalubres e separados, por muros, dos ambientes rurais. Mas as cidades fechadas pelas muralhas não impediram, em função da crescente mobilidade, dos contatos marítimos, que os navios atracassem nos portos mediterrâneos trazendo, além de especiarias, a peste. A cólera, que consumiu, entre 1848 e 1848, "50 mil vidas na Inglaterra e no País de Gales” era distinta da peste negra, já que demandava um vetor de transmissão (pulgas abundantes nos ratos $)^{30}$. Entre a peste negra e a cólera, somada a outras doenças do século XX, a COVID-19 aparece como síntese. Resultado, do ponto de vista do contágio, do fluxo aéreo, encontrou, em cidades que repetem o enredo vitoriano, ambiente fértil para sua propagação. Como na Londres vitoriana, o enfrentamento à COVID-19 repete, ao mesmo tempo, as estratégias de isolamento dos proprietários e a necessidade de manutenção do quadro de exploração do trabalho. 0 trabalhador vulnerável e a trabalhadora vulnerável aparecem como "vetores secundários" da doença. Mas, isso não pode, ao juízo dos "vetores primários", proprietários, homens 

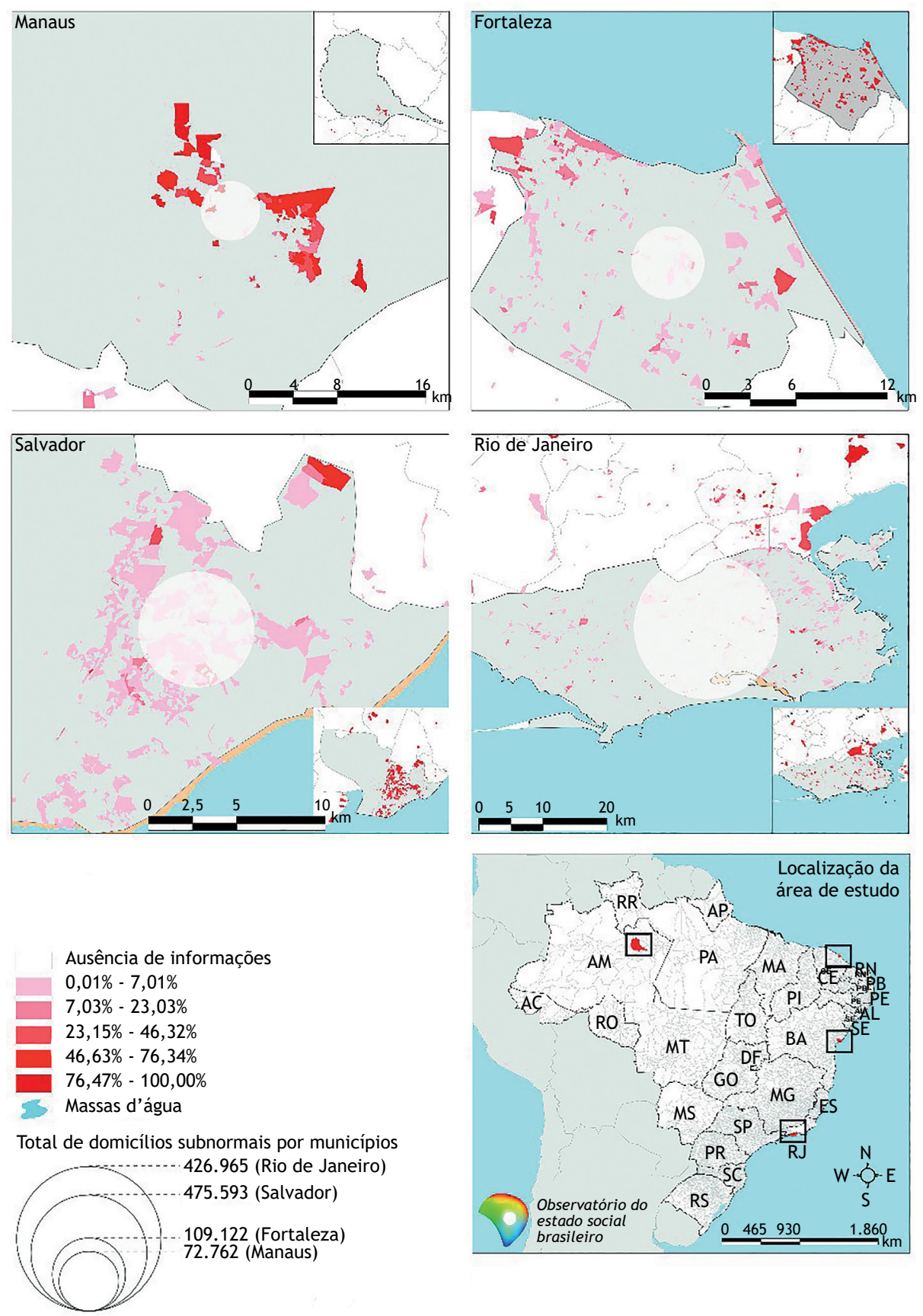

Fonte: Elaborado pelos autores com base nos dados de IBGE ${ }^{12}$

Figura 8. Percentual de domicílios subnormais não atendidos pela rede geral de distribuição de água, municípios selecionados, 2010

e mulheres de negócio, empreendedores, classe média sedenta pelo consumo etc., comprometer a geração e a acumulação de riqueza que depende da intensa exploração do trabalho - haverá, sempre, mão de obra disponível nos celeiros metropolitanos.

Mas, a fragmentação do tecido urbano e a segregação residencial nunca impediram o contato entre diferentes ambientes de moradia e de consumo. Guy Debord, ao escrever sobre a sociedade do espetáculo, anotou: "O espetáculo reúne o separado, mas o reúne como separado" ${ }^{31}$. A integração é, ao mesmo tempo, um imperativo da acumulação e causa do desespero dos acumuladores. O mapa da dispersão da COVID-19, portanto, é produto da integração de diferentes circuitos do trabalho, da produção, do consumo e do lazer, mas, sobretudo, da negligência do poder público diante das demandas acumuladas das áreas mais vulneráveis, socialmente, do país. É o grau de integração que determina o sentido da dispersão, o que, nos ambientes metropolitanos, adquire contornos dramáticos. Não é por acaso que assistimos à concentração de notificações e óbitos nas regiões metropolitanas. A variação do percentual de concentração das notificações de casos, como demostra a Figura 9 , 

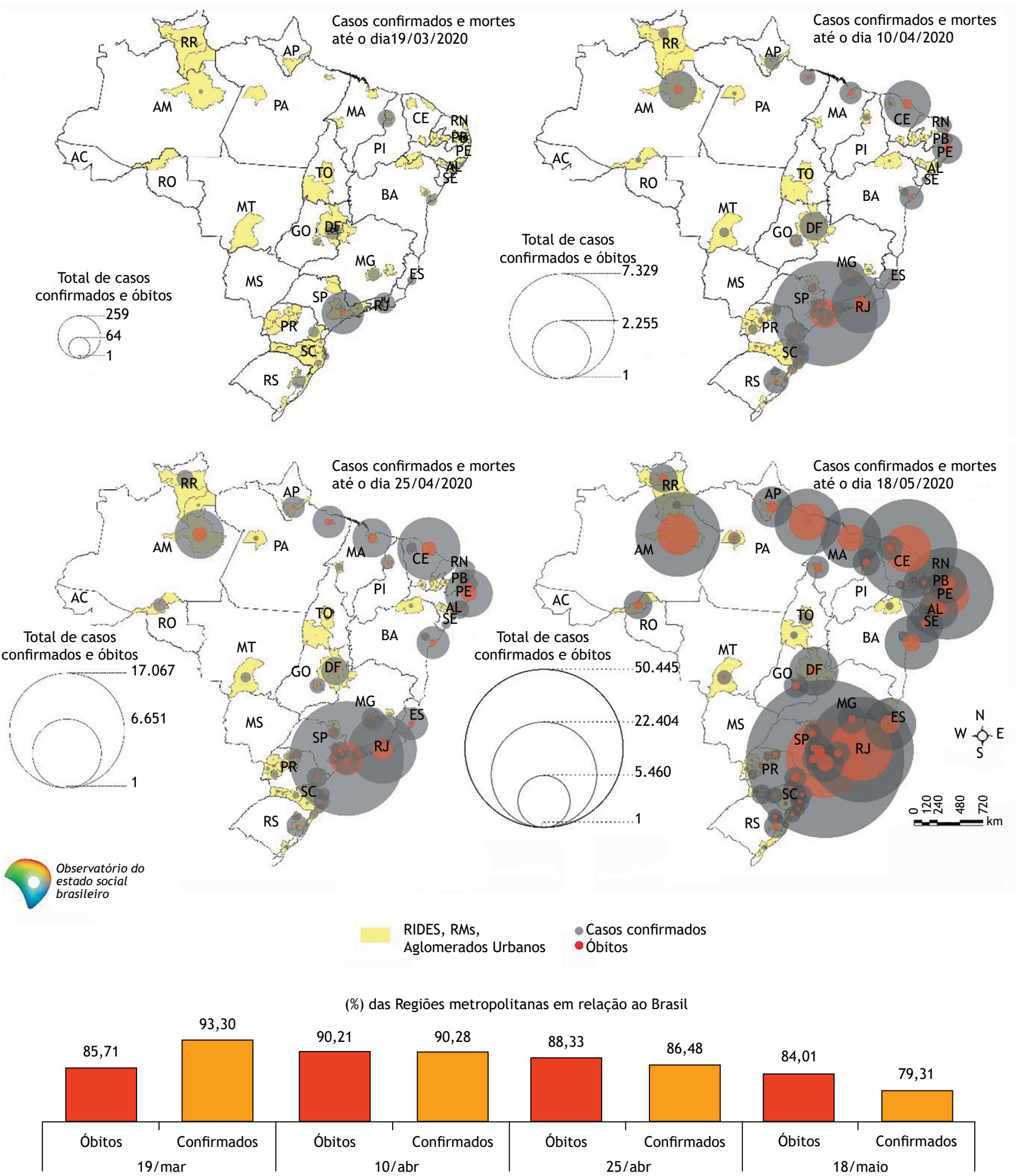

Fonte: Elaborado pelos autores com base nos dados das Secretárias Estaduais de Saúde?.

Figura 9. Evolução dos casos e óbitos do COVID-19, Regiões Metropolitanas do Brasil, em períodos selecionados.

assim como de óbitos, demonstra um forte potencial centrífugo, exercido pelas metrópoles. A concentração da doença e dos efeitos na erosão da renda será seguida, em função dos padrões de integração da rede urbana, da dispersão da doença e consequente dispersão dos efeitos econômicos e sociais da pandemia.
O efeito será escalar. Do core metropolitano para as periferias metropolitanas e das periferias metropolitanas para as demais regiões do país, em lógica que segue o modelo de estruturação da rede urbana brasileira. Um exemplo confirma essa hipótese: Águas Lindas de Goiás, cidade do Entorno do Distrito Federal, 
registrou, em 25 de abril de 2020, seis casos confirmados e nenhum óbito resultando da COVID-19. O Distrito Federal, no mesmo dia, registrou 989 casos e 26 óbitos $^{9}$. Um limite imaginário, considerando a dinâmica da COVID-19, separa o Distrito Federal de Águas Lindas de Goiás. Relatório divulgado pelo Observatório das Metrópoles sobre o Distrito Federal aponta que os primeiros casos confirmados de contaminação por SARS-CoV-2 concentravam-se em áreas de maior renda, como o Plano Piloto e o Lago Sul, além do Sudoeste/Octogonal, Águas Claras e Guará32.

Águas Lindas de Goiás reproduz, em linhas gerais, padrão de integração e migração para trabalho e estudo semelhantes aos demais espaços metropolitanos brasileiros. 0 baixo percentual de empregos formais justifica-se, em parte, pela relação de dependência com o Distrito Federal. A migração é resultado, em primeiro lugar, do trabalho, em segundo, da busca por serviços de educação e saúde. Na cidade prevalecem empregos com baixos salários, também imperando a informalidade. A conjunção entre padrão de integração do mercado de trabalho, desigual do ponto de vista das remunerações, e intensa fragmentação do tecido urbano, indicado pela ocupação desigual do solo urbano, é um dos aspectos que singulariza os espaços metropolitanos brasileiros. Essa diferença, de ordem territorial, deveria ser considerada como ponto de partida para execução de programas de recomposição e suplementação de renda na escala nacional. Os efeitos da crise não são socializados, do ponto de vista social e nem homogêneos, do ponto de vista territorial. A erosão da renda formal atinge setores de comércio e serviços, marcados por baixos salários e localizados, fundamentalmente, nas regiões metropolitanas. A suplementação da renda, via mercado informal, característica intrínseca do mercado de trabalho metropolitano, em virtude da redução de renda e dos diferentes níveis de isolamento social, também foi erodida. É justo supor, e os dados preliminares provam a hipótese, que o total de vínculos empregatícios formais já é menor que o total de trabalhadores do mercado informal. Isso tem um rebatimento imediato nas regiões metropolitanas, reverberando na redução do consumo de bens e serviços, fundamentalmente, nas periferias metropolitanas que aumentarão, sem sombra de dúvida, a pobreza e os níveis de desigualdade social. A situação exige forte presença do Estado. É claro que os espaços periféricos também encontram formas específicas de ajuda mútua. Essa dimensão, a exemplo do que tem sido feito pela Central Única das Favelas (CUFA), por intermédio da campanha Mães da Favela, é um modelo de ação solidária de forte impacto social. Essas ações, ao contrário de substituir a ação do Estado, manifestam, por meio da visibilidade da periferia, a necessidade de políticas públicas nos diferentes campos de ação que só, em função da escala, podem ser executadas por um Estado comprometido com o desenvolvimento social e com a democracia.

\section{CONCLUSÕES}

\section{Conclusão ou falso dilema de Sofia}

O fogo no celeiro humano não ocorre de forma espontânea. A combustão tem sido, milimetricamente, planejada. 0 padrão de urbanização, marcado pela densificação, ausência de serviços públicos e insalubridade, construiu um fértil ambiente para proliferação das doenças do passado, do presente, assim como do futuro. Em meio a profusão de analogias, de forte impacto emotivo, mas com baixo conteúdo explicativo, a referência a "escolha de Sofia" é a mais frequente. A metáfora permite pensar o presente, mas elimina, no entanto, o passado. As manchetes traduzem bem esse pensamento: "Setores Oeste e Bueno concentram maioria dos casos confirmados de coronavírus em Goiânia, diz Universidade Federal de Goiás" 33 e "Mapa mostra divisão dos casos de coronavírus por bairro no Rio: Barra tem mais" ${ }^{34}$. Trata-se, considerando Goiânia, de bairros habitados por uma fração abastada da cidade, menos desigual, no entanto, que o Rio de Janeiro, especialmente quando comparamos a Barra da Tijuca com o conjunto de "Aglomerados Subnormais" daquela cidade. As manchetes induzem, no primeiro momento, a pensar a democratização da doença e a consequente socialização dos riscos. Entretanto, a convergência de outras informações contradiz a premissa da escolha de Sofia, por alguns motivos:

- A notificação mais ágil nas áreas abastadas resultou e resultará, invariavelmente, em correlato acionamento prioritário da infraestrutura hospitalar, indiferente se privada e/ou pública, de modo que a demanda solvável foi aquela primeiramente atendida - os primeiros que chegaram não passaram pelo constrangimento da escolha ou mesmo a espera por leitos de UTI no SUS.

- O atraso nas notificações, fundamentalmente nas áreas periféricas, resultará em uma demanda intensa em um sistema de saúde já congestionado e, portanto, aos pobres não caberá a escolha entre "quem viverá ou morrerá". Por mais cruel que possa ser, o diagnóstico de Guilherme Benchimol, fundador da XP, expressa a realidade do um país: "[...] 0 pico da doença já passou quando a gente analisa a classe média, classe média alta" - ironicamente, não foram os pobres os primeiros a depender do SUS ${ }^{35}$.

- Os pobres não podem aderir às medidas preventivas de isolamento social, mesmo porque o funcionamento de uma série de atividades, caracterizadas como serviços essenciais, é por eles conduzido. A decisão de arriscar-se nos trabalhos precários nas casas de patrões ou em motos e bicicletas pela cidade e até mesmo na litúrgica humilhação na busca por $\mathrm{R} \$ 600,00$ jamais pode ser interpretada como escolha - trata-se de um ato compulsório para a reprodução da vida cotidiana.

O dilema contemporâneo efetivamente está relacionado à responsabilidade ética de identificar e demonstrar os desdobramentos socioespaciais da pandemia. Em que pese a sua abrangência, é evidente que há grupos mais vulneráveis e suscetíveis aos efeitos econômicos e sanitários que estão emergindo. Ser velho e pobre em países como Espanha ou Itália, que ainda guardam os benefícios da proteção de um Estado-Social edificado no pós-guerra, é bem diferente do que ser velho e pobre em um país como o Brasil, em que as formas de proteção social têm sido solapadas pelas sucessivas medidas neoliberalizantes. Não há solução para amenizar os efeitos da pandemia, senão a forte presença do Estado tanto no fortalecimento do sistema de saúde pública, aproveitando-se da 
abrangência e solidez do SUS, quanto na implementação e no aprimoramento das políticas de transferência de renda direta e indireta. Somente a justaposição de medidas econômicas e sanitárias poderá arrefecer a curto, médio e longo prazo, os efeitos deletérios da atual pandemia e de outras que provavelmente virão, dado o modelo de desenvolvimento em vigência.

\section{REFERÊNCIAS}

1. Melo ML. Primeira vítima do RJ era doméstica e pegou coronavírus da patroa no Leblon. UOL Notícias. 19 mar 2020[acesso 5 maio 2020]. Disponível em: https://noticias.uol.com.br/saude/ultimas-noticias/ redacao/2020/03/19/primeira-vitima-do-rj-era-domesticae-pegou-coronavirus-da-patroa.htm

2. Costa F, Rebello A. Após boom em enterros, Manaus abre covas coletivas para vítimas de COVID-19. UOL notícias. 21 abr 2020[acesso 5 maio 2020]. Disponível em: https://noticias.uol.com.br/saude/ultimasnoticias/redacao/2020/04/21/apos-boom-em-enterrosmanaus-abre-covas-coletivas-para-vitimas-de-covid-19. htm?cmpid=copiaecola

3. Daves M. O monstro bate à nossa porta: a ameaça global da gripe aviária. Rio de Janeiro: Record; 2006.

4. Oliveira JJ. Até liberais, que defendem estado enxuto, apoiam ajuda do governo. UOL Economia. 28 mar 2020[acesso 25 abr 2020]. Disponível em: https://economia.uol.com.br/noticias/ redacao/2020/03/28/coronavirus-cria-consenso-entreeconomistas-sobre-papel-do-estado.htm?cmpid=copiaecola

5. O'Connor J. USA: a crise do estado capitalista. Rio de Janeiro: Paz e Terra; 1977.

6. Suplicy E. Renda básica de cidadania. Porto Alegre: LP\&M, 2006.

7. Ministério da Saúde (BR). Cadastro nacional de estabelecimentos de saúde. Brasília: Datasus; 2019[acesso 9 maio 2020]. Disponível em: http://tabnet.datasus.gov.br/ cgi/cnes/NT_RecursosFísicos.htm

8. Instituto Brasileiro de Geografia e Estatísticas - IBGE. Estimativas populacionais. Rio de Janeiro: Instituto Brasileiro de Geografia e Estatísticas; 2019[acesso 5 maio 2020]. Disponível em: https: / /www.ibge.gov. br/estatisticas-novoportal/sociais/populacao/9103estimativas-de-populacao. $h$ tml?=\&t=o-que-e

9. Justen A. COVID-19: boletins informativos e casos do coronavírus por município por dia. Brasil. io. 2020[acesso 13 maio 2020]. Disponível em: https://brasil.io/dataset/covid19/caso/

10. Instituto Brasileiro de Geografia e Estatísticas - IBGE. Censo demográfico 2010: universo: aglomerados subnormais. Rio de Janeiro: Instituto Brasileiro de Geografia e Estatísticas; 2011[acesso 3 abr 2020]. Disponível em: https://sidra.ibge.gov.br/home/pmc/brasil

11. Instituto Brasileiro de Geografia e Estatísticas - IBGE. Síntese das informações sociais. Rio de Janeiro: Instituto Brasileiro de Geografia e Estatísticas; 2018[acesso 8 abr 2020]. Disponível em: https://www.ibge.gov.br/ estatisticas/sociais/saude/9221-sintese-de-indicadoressociais.html?=\&t=resultados
12. Instituto Brasileiro de Geografia e Estatísticas - IBGE. Censo demográfico de 2010. Rio de Janeiro: Instituto Brasileiro de Geografia e Estatísticas; 2010[acesso $27 \mathrm{abr}$ 2020]. Disponível em: https://sidra.ibge.gov.br/pesquisa/ censo-demografico/demografico-2010/inicial

13. Ministério do Desenvolvimento Social (BR). Relatório de programas e ações. Brasília: Ministério do Desenvolvimento Social; 2019[acesso 29 mar 2020]. Disponível em: https://aplicacoes.mds.gov.br/sagi/ri/relatorios/mds/ ?localizaDivisao $=\%$ C $3 \% 81$ guas + Lindas + de + Goi\%C3\%A1s\&codigo=52\&aM=0

14. Instituto Nacional de Seguridade Social - INSS. Estatísticas municipais. Brasília: Instituto Nacional de Seguridade Social; 2019[acesso 27 abr 2020]. Disponível em: http://www.previdencia.gov.br/dados-abertos/ estatisticas-municipais-2019/

15. Antunes R. O privilégio da servidão: o novo proletariado de serviço na era digital. São Paulo: Boitempo; 2018.

16. Ministério do Trabalho e Emprego (BR). Relatório anual de informações sociais. Brasília: Ministério do Trabalho e Emprego; 2018[acesso 5 maio 2020]. Disponível em: http://www.rais.gov.br/sitio/index.jsf

17. Ministério da Indústria, Comércio Exterior e Serviços (BR). Portal do empreendedor: estatísticas. Brasília: Sebrae; 2020[acesso 6 abr 2020]. Disponível em: http://www.portaldoempreendedor.gov.br/estatisticas

18. Instituto Nacional de Seguridade Social - INSS. Índice de preço consumidor amplo. Brasília: Instituto Nacional de Seguridade Social; 2020[acesso 2 maio 2020]. Disponível em: https://sidra.ibge.gov.br/tabela/7061

19. Departamento Intersindical de Estatística e Estudos Socioeconômicos - DIEESE. Análise da cesta básica. Brasília: Departamento Intersindical de Estatística e Estudos Socioeconômicos; 2020[acesso 24 abr 2020]. Disponível em: https://www.dieese.org.br/ analisecestabasica/2020/202003cestabasica.pdf

20. Prefeitura de Belo Horizonte. Tarifas e integrações. Belo Horizonte: BHTrans; 2020[acesso 7 abr 2020]. Disponível em: https://prefeitura.pbh.gov.br/bhtrans/informacoes/ transportes/onibus/tarifas-e-integracao

21. Governo do Estado de Pernambuco. Tarifas de serviços de segunda a sábado. Recife: Grande Recife; 2020[acesso $7 \mathrm{abr}$ 2020]. Disponível em: https: //www.granderecife.pe.gov.br/ sitegrctm/transporte/dados-e-estatisticas/tarifas/

22. Instituto Brasileiro de Geografia e Estatísticas - IBGE. Regiões metropolitanas, aglomerações urbanas e regiões integradas de desenvolvimento. Rio de Janeiro: Instituto Brasileiro de Geografia e Estatísticas; 2019[acesso 26 abr 2020]. Disponível em: https: //www.ibge.gov. 
br/geociencias/organizacao-do-territorio/estruturaterritorial/18354-regioes-metropolitanas-aglomeracoesurbanas-e-regioes-integradas-dedesenvolvimento. html?edicao $=24461 \mathrm{kt}=$ downloads

23. Ministério do Desenvolvimento Social (BR). Relatório de programas e ações (v. 2017). Brasília: Ministério do Desenvolvimento Social; 2020[acesso 13 maio 2020]. Disponível em: https://aplicacoes.mds.gov.br/sagi/ri/ relatorios $/ \mathrm{mds} /$ ?localizaDivisao $=$ assis\&codigo $=0 \& a M=0$

24. Arrais TA. A questão social, a previdência rural e a capitalização econômica da escala municipal. Bol Goiano Geo. 2017;37(2):193-220. https://doi.org/10.5216/bgg.v37i2.49152

25. Instituto Brasileiro de Geografia e Estatísticas - IBGE. Pesquisa nacional por amostra de domicílios continua: glossário. Rio de janeiro: Instituto Brasileiro de Geografia e Estatísticas; 2020[acesso 7 abr 2020]. Disponível em: ftp://ftp.ibge.gov.br/Trabalho_e_Rendimento/Pesquisa_ Nacional_por_Amostra_de_Domicilios_continua/Mensal/ glossario_pnadc_mensal.pdf

26. Secretaria Especial de Comunicação da Cidade de São Paulo - Seccsp. Prefeitura de São Paulo divulga censo da população em situação de rua 2019. Cidade de São Paulo Notícias. 31 jan 2020[acesso 4 maio 2020]. Disponível em: http://www.capital.sp.gov.br/noticia/prefeitura-de-saopaulo-divulga-censo-da-populacao-em-situacao-de-rua-2019

27. Engels F. A situação da classe trabalhadora na Inglaterra. São Paulo: Global; 1985.

28. Geddes P. Cidades em evolução. Campinas: Papirus; 1994.

29. Kelly J. A grande mortandade. Rio de Janeiro: Bertrand; 2011.
30. Johnson S. O mapa fantasma. Rio de Janeiro: Zahar; 2008.

31. Debord G. A sociedade do espetáculo. Rio de Janeiro: Contraponto; 1997.

32. Pacheco MO, Adriano HSR, Correia LA, Schatan R, Dias CM. As desigualdades na área metropolitana de Brasília e os perigos do coronavírus (COVID-19). Brasília: Universidade de Brasília; 2020[acesso 27 abr 2020]. Disponível em: https://www.observatoriodasmetropoles.net.br/ wp-content/uploads/2020/04/ARTIGO_As-desigualdades-noDF-Metropolitano-e-os-perigos-do-coronavi\%CC\%81rus.pdf

33. Jornal Anhanguera 1. Setores Oeste e Bueno concentram maioria dos casos confirmados de coronavírus em Goiânia. Portal G1 Goiás. 8 abr 2020[acesso 8 abr 2020]. Disponível em: http://g1.globo.com/goias/videos/t/todos-osvideos/v/setores-oeste-e-bueno-concentram-maioria-doscasos-confirmados-de-coronavirus-em-goiania/8466794/

34. Redação $O$ Globo. Mapa mostra divisão dos casos de coronavírus por bairro no Rio: Barra tem mais. 0 Globo. 17 mar 2020[acesso 8 abr 2020]. Disponível em: https://oglobo.globo.com/sociedade/coronavirus/mapamostra-divisao-dos-casos-de-coronavirus-por-bairro-no-riobarra-tem-mais-24311155

35. Mouro J. Pico de COVID-19 nas classes altas já passou; o desafio é que o Brasil tem muita favela, diz presidente da XP. Folha de São Paulo. 5 maio 2020[acesso 5 maio 2020]. Disponível em: https://www1.folha.uol.com.br/ mercado/2020/05/brasil-esta-indo-bem-no-controledo-coronavirus-e-pico-nas-classes-altas-ja-passou-dizpresidente-da-xp.shtml

Contribuições dos Autores

Arrais TA, Oliveira AR - Concepção, planejamento (desenho do estudo), análise, interpretação dos dados e redação do trabalho. Viana JL, Alencar DP, Salgado TR - Aquisição, análise, interpretação dos dados e redação trabalho. Moraes Neto JP - Aquisição e interpretação dos dados. Souza ME - Redação do trabalho. Todos os autores aprovaram a versão final do trabalho.

Conflito de Interesse

Os autores informam não haver qualquer potencial conflito de interesse com pares e instituições, políticos ou financeiros deste estudo.

Esta publicação está sob a licença Creative Commons Atribuição 3.0 não Adaptada.

Para ver uma cópia desta licença, visite http://creativecommons.org/licenses/by/3.0/deed.pt_BR. 